\title{
MENGENAL \\ METODE TAFSIR TAHLILI
}

Syaeful Rokim

Dosen Prodi IAT STAI Al-Hidayah Bogor

\begin{abstract}
Abstrak
Metode tafsir tahlili merupakan salah satu metode dalam penelitian tafsir.Metode tahlili berusaha menganalisa dan menjelaskan ayat-ayat al-Qur'an secara keseluruhan dan komprehensif.Penjelasannya meliputi bacaan ayat, bangunan nahwu dan sharaf, sebab nuzul ayat, makna gelobal dari ayat, hikmat pensyariatan dan lainnya.Tafsir al-Qur'an yang menggunakan metode ini sangat bermanfaat bagi para penuntut ilmu khususnya bidang ilmu al-Qur'an untuk memperdalam pemahamannya tentang al-Qur'an dan Tafsir.Hanyasaja tidak tepat bagi para pemula.
\end{abstract}

\section{Keyword: Tafsir tahlili, Metode Tafsir, Tahlili}

\section{A. Pendahuluan}

Pembahasan tafsir merupakan hal yang penting pada setiap waktu dan tempat. Hal itu dikarenakan kebutuhan umat Islam akan petunjuk yang terkandung di dalam al-Qur'an al karim untuk menjalani kehidupan di dunia ini. Adapun kebutuhan petunjuk manusia sangat beragam satu sama lainnya dalam satu daerah, atau masa dahulu dengan masa kontemporer. Oleh karena itu tafsir al-Qur'an membutuhkan aktualisasi agar dapat mudah dipahami oleh masyarakat Muslim dengan realita mereka yangberbeda-beda adat kebiasaannya.

Para ahli tafsir pun berusaha untuk menafsirkan al Qur'an dengan pendekatan dan metode yang berbeda-beda antara satu ahli tafsir dengan lainnya.Mengenai pendekatan tafsir yang melihat pada sumber penafsiran, ahli tafsir mengkategorikan tafsir al-Qur'an menjadi 4 kategori; pertama tafsir bil ma'tsur (riwayah).Kedua, tafsir bil ra'yi (dirayah).Ketiga, tafsir bil-lughah (bahasa).Keempat, tafsir isyari. 
Adapun metode tafsir yang digunakan oleh para ahli tafsir dalam penafsiran al Qur'an dapat dikategorikan menjadi empat metode; Pertama, Metode tafsir Ijmali.Kedua, metode tafsir tahlili.Ketiga, metode tafsir maudhu'i.Keempat, metode tafsir muqoron.Pembagian kategori ini merupakan pengkategorian baru, karena kategori ini muncul setelah penelitian pada buku-buku tafsiryang beragam, sehingga para ahli ilmu membagi metode tafsir yang digunakan oleh para ahli tafsir menjadi 4 macam.

Metode tahlili merupakan metode penafsiran yang digunakan oleh para ulama dahulu dan paling luas cakupan bahasannya. Hal itu dikarenakan mufasir membagi beberapa jumlah ayat pada satu surat dan menjelaskannya kata perkata secara rinci dan komprehensif.

Pada kesempatan ini, penulis berusaha untuk membahas metode tafsir tahlili.Dari empat metode penafsiran yang dijelaskan di paragraph sebelumnya, makalah ini membatasi pembahasannya pada metode penafsiran tahlili.

\section{B. Makna Metode Tafsir Tahlili}

Sebelum masuk pada pembahasan isi metode tafsir tahlili, penulis berusaha mengungkapkan definisi kata metode, tafsir dan tahlili.Tafsir tahlili merupakan bentuk kata majemuk yang terbentuk dari dua kata.Kata ini membutuhkan penjelasan pada setiap bagiannya sebelum menjelaskan definisi dari tafsir tahlili.

Kata metode berasal dari bahasa Latin yaitu berasal dari kata methodos. Kata methodos itu sendiri berasal dari akar kata metadan hodos. Meta berarti 'menuju, melalui, mengikuti, sesudah', sedangkan hodos berarti 'jalan, cara, dan arah'.Sedangkan kata metode atau dalam bahasa inggris 'methode' berarti prosedur atau proses untuk mencapai apa yang diinginkan. ${ }^{59}$ Dalam kamus besar bahasa Indonesia, kata metode berarti cara teratur yang digunakan untuk melaksanakan suatu pekerjaan agar tercapai sesuai dengan yang dikehendaki; cara kerja yang bersistem untuk memudahkan pelaksanaan suatu kegiatan guna mencapai tujuan yang ditentukan. ${ }^{60}$

59. Definition Of Method, Accessed Oktober 2017. https://www.merriamwebster.com/dictionary/method

${ }^{60}$. Definisi kata metode, diakses oktober 2017, https://kbbi.kemdikbud.go.id/ entri/metode 
Kata tafsir berarti al Tawdi>h 'penjelasan' dan al-bayan 'penegasan' serta menyikap sesuatu yang tertutup ${ }^{61}$.Ini seperti kata 'tafsir' yang disebutkan dalam firman Allah swtsurat al Furqan ayat ke 33 yang bermakna penjelasan. ${ }^{62}$ Adapun kata tafsir secara istilah kelimuan adalah ilmu yang membahas tentang al Qur'an al Karim dari segi dilalah (petunjuk)nya yang diinginkan oleh Allah sesuai kemampuan manusia. ${ }^{63}$ Imam al-Zarkasyi mengatakan bahwa ilmu untuk memahami kitabullah yang diturunkan kepada Nabi kita Muhammad saw, untuk menjelaskan makna-maknanya, untuk mengeluarkan hukum dan hikmah di dalamnya. Hal itu akan membutuhkan ilmu bahasa, nahwu (grammer), sharaf, ushul fiqih, qiraat dan lainnya. Dan membutuhkan juga pengetahuan asbab nuzul, nasikh dan mansukh. ${ }^{64}$ Imam Abu Hayyan rhm juga menjelaskan bahwa tafsir adalah ilmu yang membahas tentang bagaimana mengucapkan lafadz al-Qur'an, membahas petunjuk-petunjuknya, hukum-hukumnya, dan membahas makna-makna yang terkandung dalam susunan ayat alQur'an. ${ }^{65}$

'حل العقدة ' contoh 'حل Sedangkan kata tahlili bentuk kata arab yang bermakna membuka ikatanmenjadi terurai ${ }^{66}$. Secara umum tahlili bermaksud menjelaskan sesuatu pada unsur-unsurnya secara terperinci.

Adapun definisi tafsir tahlili secara istilah adalah metode yang digunakan seorang mufasir dalam menyingkap ayat sampai pada kataperkatanya, dan mufasir melihat petunjuk ayat dari berbagai segi serta menjelaskan keterkaitan kata dengan kata lainnya dalam satu ayat atau beberapa ayat.Tidak ditemukan definisi pada ulama terdahulu, dikarenakan metode ini dikenalkan setelahnya.

${ }^{61}$. Ibnu Faris, Maqa>yis al-Lugah hal 355.

62. Allah swt berfirman:

tidaklah orang-orang kafir itu datang kepadamu (membawa) sesuatu yang ganjil, melainkan Kami datangkan kepadamu suatu yang benar dan yang paling baik penjelasannya. (QS. Al-Furqan: 33)

63. Muhammad Abd al Adzim al-Zarqa $>$ ni, Mana>hil al Urfa $>n$ fi Ilm al Qur'an (Beirut: Dar al-Kitab al-Arabi, 1995) hal 2/6.

${ }^{64}$. Muhammad Abdullah al-Zarkasyi, Al-Burhan fi 'Ulum al-Qur'an (Kairo: Dar 1-Turats, 1984) juz 1/13.

65. Muhammad Yusuf, Abu Hayyan, Al-Bahru al-Muhith (Beirut: Dar al-Kutub al-Ilmiyah, 1993) juz 1/121.

66. Muhammad al-Ra>zi, Mukhtar al Shihah, (Kairo: al-Saktah al-Jadid, 1329H) hal 411. 
Menurut Musaid al Thayyar, tafsir tahlili adalah mufasir bertumpu penafsiran ayat sesuai urutan dalam surat, kemudian menyebutkan kandungannya, baik makna, pendapat ulama, I'rab, balaghah, hukum, dan lainnya yang diperhatikan oleh mufasir. Jadi tafsir tahlili dapat kita katakan; bahwa mufassir meneliti ayat al Qur'an sesuai dengan tartib dalam mushaf baik pengambilan pada sejumlah ayat atau satu surat, atau satu mushaf semuanya, kemudian dijelaskan penafsirannya yang berkaitan dengan makna kata dalam ayat, balagahnya, I'rabnya, sebab turun ayat, dan hal yang berkaitan dengan hukum atau hikmahnya. ${ }^{67}$

\section{Urgensi Metode Tafsir Tahlili dan Kelebihannya}

Metode tafsir tahlili atau metode tafsir yang digunakan oleh ahli tafsir sepanjang masa memiliki banyak faidah yang beragam, dan tujuan yang tinggi. Secara gelobalnya penulis jelaskan sebagai berikut:

Pertama, metode ini meneliti setiap bagian nash al qur'an secara detail, tanpa meninggalkan sesuatupun. Sehingga metode ini memberi pengetahuan yang komprehensif mengenai ayat yang dibahas baik kata atau kalimat. Di mana metode ini menyajikan makna dan hukum yang terkandung dalam nash.

Kedua, metode ini menyeru peneliti dan pembacanya untuk mempelajari/mendalami ilmu-ilmu al qur'an yang beragam.Untuk itu mufasir menjelaskan ayat dari berbagai segi dengan metode tahlili ini.

Ketiga, metode ini memperdalam pemikiran, dan menambah kuat dalam menyelami makna ayat, serta tidak puas hanya melihat makna gelobal saja.Sehingga metode ini dapat membantu dalam meningkatkan kemampuan untuk ber-istinbat, memilih ragam makna, memilih pendapat yang kuat dari pendapat para ulama.

Keempat, dari metode ini, seorang alim dapat menggunakan informasi dalam tafsir tahlili menjadi sebuah pembahasan tersendiri, seperti metode tafsir maudhui.Oleh karena itu tafsir tahlili menjadi pengantar atau asas untuk tafsir maudhui.

Adapun kesimpulan kelebihan metode tafsir tahlili dapat dijelaskan menjadi dua bagian.Pertama, ruang lingkup yang luas

67. Musa'id al-Tayyar, su'al an al-tafsir al-tahlili, http://www.attyyar.net/ container.php? fun=artview\&id $=335$ 
padametode tafsir tahlili.Karena dalam tafsir tahlili, mufassir berusaha menjelaskan ayat demi ayat secara rinci dan komprehensif.Kedua, dalam metode tafsir tahlili, seorang mufassir mendapatkan ruang yang luas untuk mengutarakan ide dan gagasannya dalam menafsirkan ayat al-Qur'an. ${ }^{68}$

Akan tetapi tafsir dengan metode tahlili kurang tepat dalam pembelajaran bagi para siswa pemula dan masyarakat awam.Hal itu dikarenakan pembahasan dalam tafsir dengan metode tahlili sangat luas dan mencakup berbagai cabang ilmu al-Qur'an dan tafsir.Sehingga hal itu menyulitkan para pemula dalam memahami ayat dan menyimpulkan maknanya.

\section{Macam-macam Metode Tafsir}

Tafsir dilihat dari metode penelitian dan penulisannya yang digunakan oleh para ulama tafsir dari zaman dahulu sampai sekarang dapat dikategorikan menjadi empat macam.Pembagian ini bukan disimpulkan oleh para ulama zaman dahulu akan tetapi pembagian metode ini muncul belakangan setelah buku-buku tafsir ditulis. Di antara macam metode tafsir sebagai berikut:

\section{Tafsir Ijmali}

Metode ini berusaha menjelaskan ayat al-Qur'an secara gelobal, ringkas dan padat, tanpa memperluas pembahasan dan memperinci penejelasan.Maksud utama metode ini adalah memperjelas makna dan bentuk kata (uslub) yang digunakan.Pada zaman Sahabat Nabi tafsir dengan metode ijmali sangat berkembang.Hal itu dikarenakan kebanyakan masyarakat waktu itu memahami sebagian besar ayat-ayat al-Qur'an, sehingga hanya sebagian kecil jumlah ayat yang perlu ditafsirkan.

Di antara contoh kitab tafsir yang menggunakan metode tafsir ijmali: Tafsir Jalalain, Tafsir al-Wajiz karangan al-Wahidi al-Naisaburi, al-Muhalla wa al-Suyuti, dan Tafsir Shofwah al-Bayan Li-Ma'ani alQur'an karangan Husain Makhluf.

68. Misy'an al-Aisawi, al-Tafsir al-Tahlili; Tarikh wa al-Tathawur, alMu'tamar al-Ilm al-Thani li-Kulliyah al-Ulum al-Islamiyah, 2012 M, hal 62. 


\section{Tafsir Tahlili}

Ini telah yang dijelaskan pada halaman sebelumnya.Sebagian besar ulama zaman dahulu menggunakan metode ini.Hanya saja, mereka berbeda-beda dalam corak penafsirannya.

Di antara contoh kitab tafsir yang menggunakan metode tafsir tahlili adalah; Tafsir Jami' al-Bayan Fi Ta'wil Ayat al-Qur'an karangan Muhammad Jarir al-Thabari, Ma'alim Tanzin karangan al-Bagawi, alBahru al-Muhith karangan Abu Hayyan al-Andalusi.Tafsir al-Qur'an al-Adzim karangan Abu Fida Ibnu Katsir.

\section{Tafsir Maudhui}

Ini merupakan metode dalam tafsir modern walaupun memiliki akar di zaman dulu, tetapi tidak seluas pembahasannya di zaman sekarang. Metode maudhui berusaha mengumulkan dan mentafsirkan ayat-ayat al-Qur'an yang memiliki tema yang sama.

Sebagian besar tafsir dengan metode maudhui ini digunakan pada penelitian-penelitian ilmiah di perguruan tinggi dan lainnya.

\section{Tafsir Muqaran}

Metode tafsir Muqaran adalah sebuah penelitian mendalam dan pengumpulan pendapat-pendapat berkaitan dengan tafsir ayat-ayat atau surat dalam al-Qur'an yang memiliki hubungan tema yang sama. Kemudian dipelajari secara mendalam untuk mengenal perkataan yang lebih rajih(kuat).Itu semua untuk mencapai petunjuk al-Qur'an yang berkaitan dengan tema yang diteliti.

\section{E. Perkembangan Tafsir Tahlili}

Adanya metode tafsir tahlili tidak secara tiba-tiba muncul.Akan tetapi metode ini muncul dengan melalui beberapa tahapan periode penafsiran.Penelitian tentang sejarah dan periode yang dilalui 'ilmu' tafsir ini, kita dapati bahwa tafsir melalui periode yang banyak, sampai pada zaman sekarang ini.Secara gelobal penjelasannya sebagai berikut;

Periode pertama, pada masa Nabi saw, tafsir waktu itu terbatas pada penjelasan pada kata-kata yang samar atau asing. Analisa tafsir secara kebahasaan kata dalam ayat di masa Nabi sangat jarang sekali, dikarenakan waktu itu masyarakat tidak membutuhkan corak tafsir 
seperti ini.Mereka sangat paham dengan bahasanya dan belum banyak tercampur dengan orang-orang asing (أعجم). ${ }^{69}$

Pada zaman Nabi saw, tafsir terfokus pada asbab nuzul. Yakni sebab diturunkannya ayat al Qur'an kepada Nabi saw. Sahabat yang menyaksikan turunnya ayat meriwayatkan kepada sahabat yang tidak sempat hadir menyaksikan turunnya ayat.Masa itu juga, ada penjelasan langsung dari Nabi saw, yaitu menyelaskan al Qur'an dengan Al Qur'an, penjelasan istilah tertentu dalam ayat, penjelasan hukum hala dan haram, atau penegasan tentang hukum yang terdapat pada ayat. Sehingga banyak hadits yang memiliki keterkaitan dengan tafsir ayat baik secara langsung atau tidak.

Pada zaman Nabi saw, tersisa banyak ayat yang tidak ditafsirkan oleh Nabi saw. Dikarenakan masyarakat waktu itu tidak membutuhkannya, atau dibiarkan agar manusia setelahnya mendalami ilmu tafsir itu dan menggunakan pemahaman mereka untuk ber-istinbat makna, hukum atau hikmah yang terkandung dalam ayat.

Periode kedua, terjadi perluasan penafsiran secara besarbesaran.Hal itu menjadi kebutuhan primer bagi orang-orang yang baru masuk Islam, di mana mereka tidak menyaksikan langsung turunnya wahyu.Muailah adanya kebutuhan tafsir secara bahasa setahap-setahap. Hingga islam menyebar di timur dan barat. Sebagaimanadinukil bahwan Umar bin Khattab memberikan perhatian khusus pada segi bahasa. Begitu pula Ibnu Abbas rda merupakan sahabat Nabi saw yang berandil besar dalam menafsirkan al qur'an al karim. ${ }^{70}$

Periode ini, keseriusan para sahabat dan tabi'in memiliki pengaruh besar dalam perkembangan tafsir.Mereka berusaha dalam menafsirkan al Qur'an berlandaskan kaidah-kaidah syariat dan bahasa.Mereka memiliki pendapat-pendapat tafsir yang diriwayatkan dan terjaga dalam buku-buku tafsir dan hadits.Hanya saja sebagian besarnya berkaitan tentang kebahasaan, atau hukum fiqih.Maka pergerakan penafsiran di daerah Islam tumbuh subur seperti madrasah Makkah. Madinah, Bashrah, Kufah dan Yaman. Oleh karena itu perkataan sahabat dan tabiin yang berkaitan dengan penafsiran ayat menjadi pilar penafsiran bil-Ma'tsur.Adapun perbedaan pendapat di antara mereka pada periode ini sangat sedikit, dan itu terjadi dalam

\footnotetext{
${ }^{69}$ Muhsin Abd al-Hamid, Tatawur Tafsir al-Qur'an.Hal 17.

70. Abd al-Rahman al-Suyuti, al Itqan fi 'Ulum al-Qur'an, (Madinah Munawarah: Majma’ al-Malik al-Fahd, 1426H) hal 1/347.
} 
masalah hukum fiqih.Walaupun terjadi perkembangan tafsir pada periode ini, al qur'an secara rincinya belum ditafsirkan seluruhnya. Baik pada masa sahabat nabi atau masa tabiin. ${ }^{71}$

Periode ketiga,periode tafsir tahlili muncul setelah ilmu-ilmu keislaman dibukukan.Dan muncul ilmu baru yang berkhidmat pada alQur'an al-Karim. Mulai analisa nash ayat al-Qur'an dengan bentuk yang lebih luas. Pada periode ini, kamus bahasa banyak dibukukan dan ilmu bahasa menjadi lebih luas, seperti nahwu, sharaf dan balaghah. Oleh karena itu terjadi peluasan penjelasan nash ayat al-Qur'an dalam ilmu bahasa arab dalam rangka menjelaskan kata-kata gharib (asing) dalam al-Qur'an. Maka ditulislah buku secara khusus yang menjelaskan makna kata dalam al-Qur'an.Seperti buku Majaz al-Qur'an yang ditulis oleh Abi Ubaidah w 210H. dia menafsirkan petunjuk kata al-Qur'an, menjelaskan bacaaan ayat dan berbicara tafsirnya secara keilmuan bahasa secara murni. ${ }^{72}$

Selain dari majaz al-Qur'an, ada buku yang bernama kutub ma'ani, seperti tafsir 'Ma'ani al-Qur'an' karangan Abi Zakaria al-Fara' w 207.Beliau lebih fokus pada kata-kata seputar bacaannya, I'rabnya dan kata turunannya.Ada juga buku 'Ma'ani al-Qur'an karangan alAkhfasy w 215, dia lebih perhatian pada suara, sifat dan tempat keluarnya huruf.Secara umum beliau menjelaskan tafsirnya secara bahasa, sharaf, nahwu dan balaghah.

Dengan meluasnya ruang analisa bahasa dalam tafsir kata-kata dalam al-Qur'an, maka perkembangan selanjutnya terjadi keluasan ruang analisa dalam istinbat (penetapan) hukum fiqih, hal ini sesuai dengan perkembangan yang maju pada madrasah-madrasah fiqih di dunia Islam. Mereka mulai mempelajari nash al-Qur'an dari segi fiqihnya saja. Oleh karena itu muncullah buku 'Ahkam al-Qur'an' karangan imam Syafi'i w 204 H, selain itu, pengikut madzhab Maliki juga menulis hal yang sama seperti Ismail bin Ishaq al-Qadhi w $282 \mathrm{H}$. begitu juga madzhab Hanafi seperti imam Al-Thahawi w $321 \mathrm{H}^{73}$

Pada periode ini juga, mucul pembukuan-pembukuan cabang ilmu-ilmu al-Qur'an seperti buku-buku tentang asbab nuzul, salah

71. Muhammad Husain al-dzahabi, al-Tafsir wa al Musfassirun, (Kairo: Maktabah Wahbah, 1976 M) Juz 1/100.

72. Muhsin abd al-Hamid, Tathawur Tafsir al-Qur'an.Hal 50.

73. Misy'an al-Aisawi, al-Tafsir al-Tahlili; Tarikh wa al-Tathawur, alMu'tamar al-Ilm al-Thani li-Kulliyah al-Ulum al-Islamiyah, 2012 M, hal 66. 
satunya yang ditulis oleh guru imam bukhari, Ali bin Al-Madini w 234 . Terbukukan juga ilmu qira'at seperti buku Abi Ubaid bin Salam w 224. Ahmad bin Zubair al-Kufi dan Ismail bin Ishaq al-Qadhi $282 \mathrm{H}$. Dibukukan juga ilmu naskh wa mansukh, yang buat oleh Qatadah alSadusi, Ibnu Syihab al-Zuhri, dan Muqatil bin Sulaiman

Periode keempat, periode penggabungan dari ilmu-ilmu yang berkaitan dengan tafsir. Buku yang paling lama dengan metode tahlili adalah buku yang ditulim oleh imam Muhammad bin Jarir al-Tabari w 310. Beliau menulis kitab tafsirnya dengan metode yang komprehensif dalam mempelajari nash al-Qur'an. Imam Suyuti rhm mengatakan,kitab tafsir al-tabari adalak kitab tafsir yang paling agung lagi mulia, karena di dalamnya dipaparkan perkataan-perkataan sahabat, tabi'in dan ulama dan merajihkannya.Terdapat juga I'rab dan instinbat dari altabari.Dengan itu, tafsir ini lebih dalam dan luas dari tafsir-tafsir terdahulu. ${ }^{74}$

Imam al-Nawawi rhm mengatakan juga tentang tafsir al-Tabari, umat sepakat bahwa belum terdapat kitab yang disusun seperti tafsir alTabari. ${ }^{75}$ Dengan demikian, imam al-tabari adalah orang pertama yang meniti jalan tafsir tahlili dan ditulis dalam buku.Terkandung di dalamnya kaidah-kaidah ilmu ini dan langkah-langkahnya.

Imam al Zarkasyi rhm mengatakan bahwa sesungguhnya Muhammad bin Jarir al-Tabari mengabarkan kepada seluruh manusia tentang penafsiran yang beragam, dan mendekatkan sesuatu yang jauh. ${ }^{76}$ Jadi dapat kita katakana bahwa tafsir Ibnu Jarir al-Tabari memiliki keutamaan tersendiri dari kitab-kitab tafsir lainnya baik dari segi waktu, segi faniyah, dan segi pembuatannya.

Setelah imam al-Tabari, imam al-Tsa'labi al-Naisaburi (w 427 H)membuat kitab tafsir al-Qur'an.Dalam penafsiranyya, beliau terpengaruh dengan metode yang digunakan oleh imam al-tabari.AlTsa'labi mengatakan di dalam pengantar kitab tafsirnya, bahwa beliau menyebutkan pendapat 14 ahli nahwu dalam tafsirnya. ${ }^{77}$ Setelahnya

74. Abd al-Rahman al-Suyuti, al Itqan fi 'Ulum al-Qur'an, (Madinah Munawarah: Majma' al-Malik al-Fahd, 1426H) 4/212.

${ }^{75}$. Muhyiddin Syarof al-Nawawi, Tahdzib al-Asma' wa al-Lugat (Beirut: Dar al-Kutub al-Ilmiyah)1/78

76. Muhammad Abdullah al-Zarkasyi, Al-Burhan fi 'Ulum al-Qur'an (Kairo: Dar 1-Turats, 1984) juz 2/76.

77. Ahmad Al-Tsa'labi, al-Kasyf wa al-Bayan, (Beirut: Dar al-Ihya' al-Turats al-Arabi 2002 M) juz 1/75. 
juga muncul kitab tafsir 'Ma'alim al-Tanzil' karangan imam al-Bagawi (w 516).

Tafsir yang lebih jelas dan dalam lagi dalam penggunaan metode tahlili adalah tafsir Ibnu Hayyan al-Andalusi (w 745), beliau menulis tafsir yang bernama 'al-Bahr al-Muhi>th'. Ibnu Hayyan dalam pengantar bukunya menjelaskan langkah-langkahnya dalam menafsirkan al-Qur'an secara terperinci dan berurutan.Beliau mengawali penafsiran ayat dengan menjelaskan mufradat ayat, yakni kata-perkata dijelaskan makna bahasa dan nahwunya.Kemudian beliau menjelaskan tafsir ayat dengan menyebutkan sebab nuzul ayat, jika memiliki asbab nuzul. Kemudian beliau menjelaskan nasakh atau tidaknya ayat yang dibahas, dan menyebutkan keterkaitan ayat dengan ayat sebelumnya, atau surat sebelumnya. Beliau juga menjelaskan macam-macam qiraat yang mutawatir dan syad.Dll. ${ }^{78}$

\section{F. Ragam Metode Tafsir Tahlili}

Dalam perkembangan penafsiran al-qur'an, metode tafsir tahlili memiliki ragam penafsiran.Ada penggabungan antara metode tafsir tahlili dengan pendekatan tafsir bil ma'tsur dan tafsir bil ra'yi (dirayah).Oleh karena itu, tafsir tahlili -minimalnya- memiliki dua ragam;

1. Tafsir tahlili bil ma’tsur

Dalam hal ini, metode tafsir tahlili berusaha menjelaskan ayatayat secara terperinci dengan menggunakan pendekatan tafsir bil ma'tsur.Adapun yang dimaksud dengan tafsir bil ma'tsur adalah penafsiran ayat-ayat al-Qur'an berlandaskan pada penjelasan dalam ayat yang lain, dan pada hadits-hadits nabawi, dan pada perkataan para sahabat dan tabi'in.

Di antara tafsir tahlili yang menggunaka pendekatan tafsir bil ma'tsur yaitu; a. Tafsir Jami' al-Bayan fi Ta'wil ayat al Qur'an, b. Ma'alim Tanzil al-Bagawi.C. tafsir al-Qur'an al-Adzim, Ibnu Kathir.D, al-Durr al-Ma'tsur fi al Tafsir bi al-Ma'tsur Suyuti. E,

${ }^{78}$. Muhammad Yusuf, Abu Hayyan, Al-Bahru al-Muhith (Beirut: Dar al-Kutub al-Ilmiyah, 1993) juz 1/103. 
2. Tafsir tahlili bil ra'yi

Ragam tafsir tahlili yang kedua adalah penggunaan pendekatan tafsir bil Ra'yi.Yakni dalam penjelasan tafsir tahlili ini, mufasir menggunakan sumber ra'yu yang didukung dengan kaidah-kaidah tafsir dan cabang-cabang ilmu tafsir.

Di antara tafsir tahlili yang menggunakan pendekatan tafsir bil ra'yi yaitu; a. Tafsir al-Khazin, al-Khazin. B, Anwar Tanzil wa Asrar Al-Ta'wil,al-Baydhawi. C, Tafsir al-Jawahir fi Tafsir al-Qur'an, Thanthawi Jauhari.D. tafsir al-Manar, Muhammad Rasyid.

\section{G. Langkah Penafsiran Tahlili}

Tidak terhenti perjalanan tafsir tahlili sampai pada ulama terdahulu saja.Metode tafsir tahlili sampai saat ini masih relevan dan dapat digunakan dalam penafsiran al-Qur'an sebagaimana perkembangan kehidupan manusia secara umum.Berikut ini ada beberapa langkah yang digunakan para ulama terdahulu dalam penafsiran al-Qur'an dengan metode tahlili; Pertama, penjelasan makna kata dalam al-Qur'an.Kedua, penjelasan asbab nuzul ayat (sebab turunnya ayat). Ketiga, penjelasan munasabah antar ayat dan surat sebelumnya. Keempat, penjelasan I'rab ayat dan macam-macam qiraat ayat. Kelima, penjelasan kandungan balagahnya dan keindahan susunan kalimatnya. Keenam, penjelasan hukum fiqih yang diambil dari ayat. Ketujuh, penjelasan makna umum dari ayat dan petunjukpetunjuknya.

Tujuh point inilah yang merupakan inti dalam metode tafsir tahlili, yang digunakan oleh para ahli tafsir terdahulu dalam buku tafsir mereka.Hanya saja langkah-langkah di atas bukan berarti harus berurutan seperti urutan di atas, tetapi itu adalah langkah secara umum para ahli tafsir dalam metode tahlili.Terkadang sebagian ahli tafsir tidak menggunakan salah satu langkah yang di atas.Atau sebagian mufasir mengedepankan makna umum dari pada penjelasan I'rab, sesuai yang dipandang penting oleh ahli tafsir (penulis) dalam tafsirnya. Sebagaimana juga ada mufassir yang tidak mengelompokkan tafsirnya seperti di atas, akan tetapi mufassir menjelaskan tafsirnya secara natsryakni campur dan menyatu antara penjelasan makna dan penjelasan lainnya.

Pada zaman kontemporer sekarang ini, Nampak jelas ada perhatian serius ada metode ini. Yakni ada tambahan langkah-langkah 
baru dari sebelumnya, atau ada pembagian bab yang jelas secara berurutan, sehingga dapat dipahami dengan mudah. Perkembangan ini banyak terjadi pada dunia akademisi, terkhusus pada akademisi jurusan tafsir, baik tafsir surat tertentu ataupun tafsir al-Qur'an secara keseluruhan.

Di antara tema bab yang ditawarkan dalam metode tafsir tahlili ini sebagai berikut: pertama, Apa faidah dari nash ayat (ما يستفاد من النص), kedua, Hikmah pensyariatan dalam ayat, ketiga, I'jaz keilmuan dalam nash al-Qur'an, keempat, Penjelasan historis masyarakat saat ayat turun, kelima, Kandungan pengetahuan individu dan sosial kontemporer.

\section{Apa faidah dari nash ayat (ما يستفاد من النص)}

Nash al-Qur'an mengandung banyak petunjuk, makna, dan isyarat.Hal ini menunjukkan tingkatan tertinggi kefasihan bahasa dan balagah.Selain itu juga, ada faidah yang diambil dari nash ayat dan ruhnya, tetapi faidah ini mengantarkan pada faidah dalam kehidupan ilmiah. Adanya langkah ini akan menjadi mengingat bagi pembacanya, atau memberikan ringkasan baginya.

langkah ini (ما يستفاد من النص) terkadang dengan nama lain

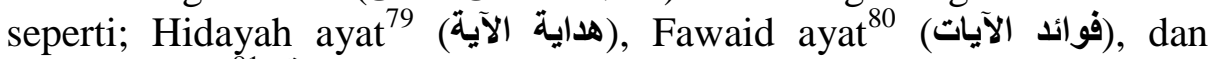
petunjuk ayat ${ }^{81}$ (ما ترشد إليه الآيات الكريمة).

2. Hikmah pensyariatan dalam ayat

Ini mungkin yang dibutuhkan dalam di masa sekarang ini.Sebagian besar masyarakat mencari penjelasan hikmah pensyariatan, agar hati mereka thuma'ninah. Mereka menyadari bahwa apa yang dibawa islam (dalam Al-Qur'an) selaras dengan akal, ilmu dan realita. Hal ini akan kita temukan dalam kitab-kitab tafsir modern seperti Rawa'I al-bayan dan al-Tafsir al-Munir.

3. I'jaz keilmuan dalam nash al-Qur'an

Ada beberapa ayat yang mengandung petunjuk pada bidang keilmuan dan penemuan ilmiah modern,seperti ilmu falak (astronomi),

${ }^{79}$, seperti yang dinamakan oleh Abu Bakar al-Jazairi dalam kitab tafsirnya 'Aisar al-Tafasir'

${ }^{80}$. seperti yang dinamakan oleh Muhammad Nashir al-Umar dalam tafsirnya pada surat al-Hujurat.

${ }^{81}$. seperti yang dinamakan oleh Muhammad Ali al-Shabuni dalam tafsir 'Rawai' al-Bayan Fi Tafsir Ayat al-Ahkam'. 
ilmu kedokteran dan lain-lain. Walaupun al-Qur'an bukan buku ilmu astronomi, kimia, kedokteran, hanya saja al-Qur'an mengobati manusia dan membentuk psikologi, akhlak, dan pemikiran.Manusia diberikan ruang untuk meneliti dan eksperimen pada bidang ilmiah (kauniyah).

Para ulama kaum Muslimin juga memandang baik dalam mengambil manfaat dari hasil penelitian tentang alam, kehidupan, dan manusia untuk memahami al-Qur'an.Hal itu dapat memperdalam pemahaman mengenai nash al-Qur'an. Hanya saja tidak boleh untuk memperkuat pendapat perorangan sedangkan tidak ada korinah yang kuat.

4. Penjelasan historis masyarakat (sosiologis) saat ayat turun

Kondisi masyarakat atau kejadian yang terjadi sebelum turunya ayat alQur'an atau apa yang terjadi di masa Nabi Muhammad saw sangat membutuhkan perincian dan penjelasan yang cukup. Sehingga pembaca dapat memahami petunjuk ayat secara hakiki.Terkadang ada isyarat pada beberapa kejadian yang membutuhkan pengetahuan yang syamil (komprehensif), dikarenakan ayat turun berkenaan tentang kejadian itu.Seperti ayat-ayat permulaan pada surat al-Mujadilah juz 28.

5. Kandungan pengetahuan insani dan sosial kontemporer seperti ilmu psikologi, ilmu sosial, ilmu ekonomi, ilmu pendidikan dan lainnya.

Tidak diragukan lagi, bahwa sebagian besar dari ilmu-ilmu yang ada di zaman sekarang ini memiliki dasar dan akar di dalam al-

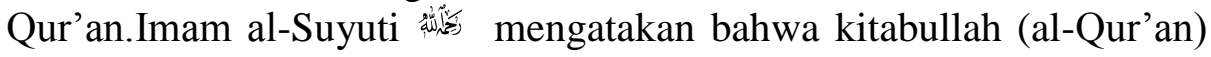
mencakup segala sesuatu (ilmu).Adapun berbagai beragam ilmu yang ada itu ada petunjuknya di dalam al-Qur'an. Pada kesempatan yang lain imam Suyuti mengatakan bahwa al-Qur'an berisikan juga ilmu-ilmu selain ilmu terdahulu, seperti kedokteran, arsitek, dan lainnya. ${ }^{82}$

Para ulama tafsir tidak melarang untuk mengambil pengetahuan manusia dalam bidang ilmu apapun dan menjadikannya sebagai khidmah pada al-Qur'an al-karim, bukan sebagai alat untuk menghukumi al-Qur'an. ${ }^{83}$

\footnotetext{
82. Imam Suyuti, al-Iklil fi istinbat al-Tartil.

${ }^{83}$. Misy'an al-Aisawi, al-Tafsir al-Tahlili; Tarikh wa al-Tathawur, al-Mu'tamar al-Ilm al-Thani li-Kulliyah al-Ulum al-Islamiyah, $2012 \mathrm{M}$, hal 75-76
} 


\section{H. Kesimpulan}

Pada akhirnya, penulis mengatakan bahwa tafsir tahlili merupakan metode tafsir yang sebagian besar para ahli tafsir menggunakannya untuk berkhidmat pada kitab Allah ta'ala. Para ahli tafsir tidak meninggalkan sesuatu yang mempedalam/memperluas ruang pemahaman ayat melainkan mereka akan menggunakan metode itu atau mengikut sertakan penjelasan itu. Akan tetapi ada perbedaan di antara mufassir itu merupakan sunnatullah.Di antara ahli tafsir ada yang menjelaskan tafsirnya secara luas (komprehensif), ada pula yang menjelaskan secara ringkas dan padat.

Pada zaman kontemporer ini, ada penambahan dalam bab atau penjelasan dalam tafsir. Zaman ini telah memberikan saham dalam menjelaskan nash al-Qur'an yang sesuai dengan tabiat zamannya. Muncul di zaman ini tafsir ilmi, yang merupakan bukti kebenaran firman Allah S.W.T. dalam bidang ilmi.Allahu a'lam 


\section{DAFTAR PUSTAKA}

Muhammad Al-Razi, Mukhtar Al Shihah, (Kairo: Al-Saktah Al-Jadid, $1329 \mathrm{H})$

Muhsin Abd Al-Hamid, Tatawur Tafsir Al-Qur'an.

Abd Al-Rahman Al-Suyuti, Al Itqan Fi 'Ulum Al-Qur'an, (Madinah Munawarah: Majma’ Al-Malik Al-Fahd, 1426H)

Muhammad Husain Al-Dzahabi, Al-Tafsir Wa Al Musfassirun, (Kairo: Maktabah Wahbah, 1976 M)

Misy'an Al-Aisawi, Al-Tafsir Al-Tahlili; Tarikh Wa Al-Tathawur, AlMu'tamar Al-Ilm Al-Thani Li-Kulliyah Al-Ulum Al-Islamiyah, $2012 \mathrm{M}$.

Abd Al-Rahman Al-Suyuti, Al Itqan Fi 'Ulum Al-Qur'an, (Madinah Munawarah: Majma' Al-Malik Al-Fahd, 1426H)

Muhyiddin Syarof Al-Nawawi, Tahdzib Al-Asma' Wa Al-Lugat (Beirut: Dar Al-Kutub Al-Ilmiyah)

Muhammad Abd Al Adzim Al-Zarqani, Manahil Al Urfan Fi Ilm Al Qur'an Beirut: Dar Al-Kitab Al-Arabi, 1995 M.

Muhammad Abdullah Al-Zarkasyi, Al-Burhan Fi 'Ulum Al-Qur'an Kairo: Dar L-Turats, 1984 M.

Ahmad Al-Tsa'labi, Al-Kasyf Wa Al-Bayan, Beirut: Dar Al-Ihya' AlTurats Al-Arabi $2002 \mathrm{M}$

Muhammad Yusuf, Abu Hayyan, Al-Bahru Al-Muhith (Beirut: Dar AlKutub Al-Ilmiyah, 1993) Juz 1/103.

Nashruddin Baidan, Metodologi Penafsiran Al-Qur'an (Jakarta: Pustaka Pelajar, 1988).

Definition Of Method, Accessed Oktober 2017. Https://Www.MerriamWebster.Com/Dictionary/Method

Definisi Kata Metode, Diakses Oktober 2017, Https://Kbbi.Kemdikbud.Go.Id/Entri/Metode

Ahmad Bin Faris, Mu'jam Maqayis Al-Lugah.Beirut: Dar Al-Fikr, 1979 M.

Musa'id Al-Tayyar, Su'al An Al-Tafsir Al-Tahlili, Http://Www.Attyyar.Net/Container.Php?Fun=Artview\&Id=335 


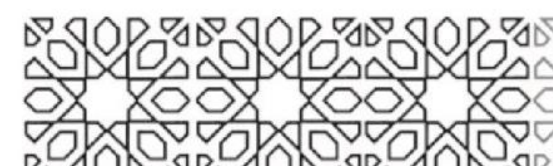

of

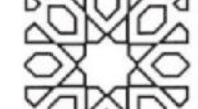

DOXODO

$\triangle \mathrm{O} O \mathrm{D}$

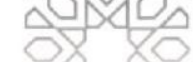

